\title{
PERSISTENCE AND RELEASE OF MACRONUTRIENTS AND SILICON OF PIGEONPEA AS A FUNCTION OF FRAGMENTATION
}

Jayme Ferrari Neto ${ }^{1}$, Carlos Alexandre Costa Crusciol ${ }^{2}$, Rogerio Peres Soratto, Claudio Hideo Martins da Costa $^{3}$, Gustavo Spadotti Amaral Castro ${ }^{4}$

Universidade Católica Dom Bosco, Campo Grande, MS. ${ }^{1}$, Universidade Estadual Paulista, Faculdade de Ciências Agronômicas, Departamento de Produção e Melhoramento Vegetal, Botucatu, SP. ${ }^{2}$, Universidade Federal de Goiás, Regional Jataí, Unidade Acadêmica Especial de Ciências Agrárias, Jataí, GO. ${ }^{3}$, Embrapa Monitoramento por Satélite, Campinas, SP. 4

\begin{abstract}
The objective of this work was to evaluate the persistence and macronutrient and silicon release of pigeonpea phytomass, with and without mechanical fragmentation. The experiment was design in randomized blocks, with four replications, arranged as $2 \times 6$ factorial combination, 2 managements (with and without fragmentation) and 6 times of phytomass harvest $(0,18,32,46,74$ and 91 days after management). The fragmentation of the phytomass did not alter decomposition and release of $\mathrm{N}, \mathrm{P}, \mathrm{Ca}, \mathrm{Mg}$ and $\mathrm{S}$, and the maximum daily release of these occurred between 0 and 18 DAM. Potassium was released faster, especially with the fragmentation of the phytomass. At the last evaluation, at least $85 \%$ of all macronutrients were released to the soil. Silicon release from the phytomass was negligible and there is an increase of the element level over time, mainly, with mechanical fragmentation.

Keywords: Cajanus cajan; cover crop; decomposition rate; nutrients recycling; phytomass management.

\section{PERSISTÊNCIA E LIBERAÇÃO DE MACRONUTRIENTES E SILÍCIO DA FITOMASSA DO GUANDU-ANÃO EM FUNÇÃO DA FRAGMENTAÇÃO}

\section{RESUMO}

Objetivou-se avaliar a persistência e a liberação de macronutrientes e Si da fitomassa do guandu-anão (Cajanus cajan) submetida ou não à fragmentação mecânica. O delineamento experimental foi em blocos casualizados, com quatro repetições, em esquema fatorial constituído por dois manejos (sem e com fragmentação mecânica) e seis épocas de coleta da fitomassa $(0,18,32,46,74$ e 91 dias após o manejo (DAM)). A fragmentação mecânica da fitomassa do guandu-anão não alterou a decomposição e a liberação de $\mathrm{N}, \mathrm{P}, \mathrm{Ca}, \mathrm{Mg}$ e $\mathrm{S}$, e as máximas taxas de liberação diária ocorreram de 0 a $18 \mathrm{DAM}$. O K foi o nutriente mais rapidamente liberado, principalmente com a fragmentação da fitomassa. Aos 91 DAM pelo menos $85 \%$ de todos os macronutrientes foram liberados ao solo. A liberação de $\mathrm{Si}$ foi baixa, sendo, proporcionalmente menor que a taxa de degradação da fitomassa o que acarretou em aumento do teor do elemento com o passar do tempo, principalmente com a fragmentação mecânica.

Palavras-chave: Cajanus cajan; cobertura vegetal; reciclagem de nutrientes; manejo da fitomassa; taxa de decomposição. 


\section{INTRODUCTION}

The cover crops species to be included into a crop rotation and succession in no-till system (NT) must produce enough biomass that promotes soil protection against erosive agents and also accumulate, and subsequently, provide nutrients to the soil during decomposition. In this context, Doneda et al. (2012) reported the importance of understanding the dynamics of decomposition and nutrients release from cover crops, and select species that have greater potential to produce biomass and to accumulate nutrients.

The pigeonpea (Cajanus cajan) is a legume commonly used in tropical and subtropical region. Adapted for wide range of precipitation, is drought tolerant and develops better at high temperatures (CALEGARI, 2000), and produces shoot dry matter (SDM) up to 6.000 $\mathrm{kg} \mathrm{ha}{ }^{-1}$ (TORRES et al., 2008). In general, compared to grasses, pigeonpea has higher decomposition rate because it is a legume with lower $\mathrm{C} / \mathrm{N}$ ratio (TEIXEIRA et al., 2009). However, is able to add great amounts of $\mathrm{N}$ to the soil through symbiotic fixation atmospheric $\mathrm{N}_{2}$ (SALMI et al., 2006) and to recycle nutrients. Thus, the pigeonpea is a good alternative to compose crop rotation in NT, since the release of nutrients during decomposition may occur quickly, providing short-term benefits to the next crop (SALMI et al., 2006; TORRES et al., 2008).

With regard to the durability of SDM, the indicators more commonly used to express the resistance to decomposition are the $\mathrm{C} / \mathrm{N}, \mathrm{C} / \mathrm{P}$ and $\mathrm{C} / \mathrm{S}$ ratios. Another indicator that has been researched is the $\mathrm{C} / \mathrm{Si}$ ratio, because the $\mathrm{Si}$ absorbed by the plants and present in the cell wall can work as a physical barrier, reducing the loss and, or, the access to the cellular material during decomposition of biomass on soil (SILVA; BOHNEN, 2001).

Regarding the SDM management, there are negative reports in the literature concerning the use of horizontal crusher straw, especially with regard to the increased cost of production and soil compaction (DENARDIN; KOCHHAN, 1993), but there are also positive outcomes related to greater nutrient cycling (PARIZ et al., 2011).

More information related to cover crops management in different soil and climatic conditions are needed, so that we can understand the dynamics of degradation and nutrient release from the species due to management in each region (PEGADO et al., 2008).

As reported by Doneda et al. (2012), it is necessary to intensify the studies related to decomposition and release of nutrients from cover crops, especially under NT. Therefore, the objective of this study was to evaluate the persistence and release of macronutrients and $\mathrm{Si}$ from pigeonpea as a function of mechanical fragmentation, under NT.

\section{MATERIAL AND METHODS}

This study was carried out at field conditions, from November 2004 to April 2005, in Botucatu, São Paulo, Brazil $\left(22^{\circ} 58^{\prime} \mathrm{S}, 48^{\circ} 23^{\prime} \mathrm{W}\right.$, $765 \mathrm{~m}$ above sea level). Soil at the location is a Red Nitisol (EMBRAPA, 2013) and the chemical characteristics of the soil $(0-20 \mathrm{~cm})$ were: $25.0 \mathrm{~g}$ $\mathrm{dm}^{-3}$ of organic matter, $\mathrm{pH}\left(\mathrm{CaCl}_{2}\right) 5.0,17.0 \mathrm{mg}$ $\mathrm{dm}^{-3}$ de $\mathrm{P}$ (resin); 1.6, 33.3, 17.6, $34.1 \mathrm{mmolc} \mathrm{dm}^{-3}$ of $\mathrm{K}, \mathrm{Ca}, \mathrm{Mg}$ and $\mathrm{H}+\mathrm{Al}$, respectively, and $61 \%$ of base saturation. In regard to textural classification, the soil has a clayey texture with $512 \mathrm{~g} \mathrm{~kg}^{-1}$ of clay, $381 \mathrm{~g} \mathrm{~kg}^{-1}$ of sand and $107 \mathrm{~g} \mathrm{~kg}^{-1}$ of silt.

According to the Köppen climate classification, the predominant climate in the region is the is $\mathrm{Cwa}$, i.e., a higher altitude tropical climate with dry winters and hot, wet summers. Reference data for average monthly temperature and total monthly rainfall throughout the experimental period are shown in figure 1 . 


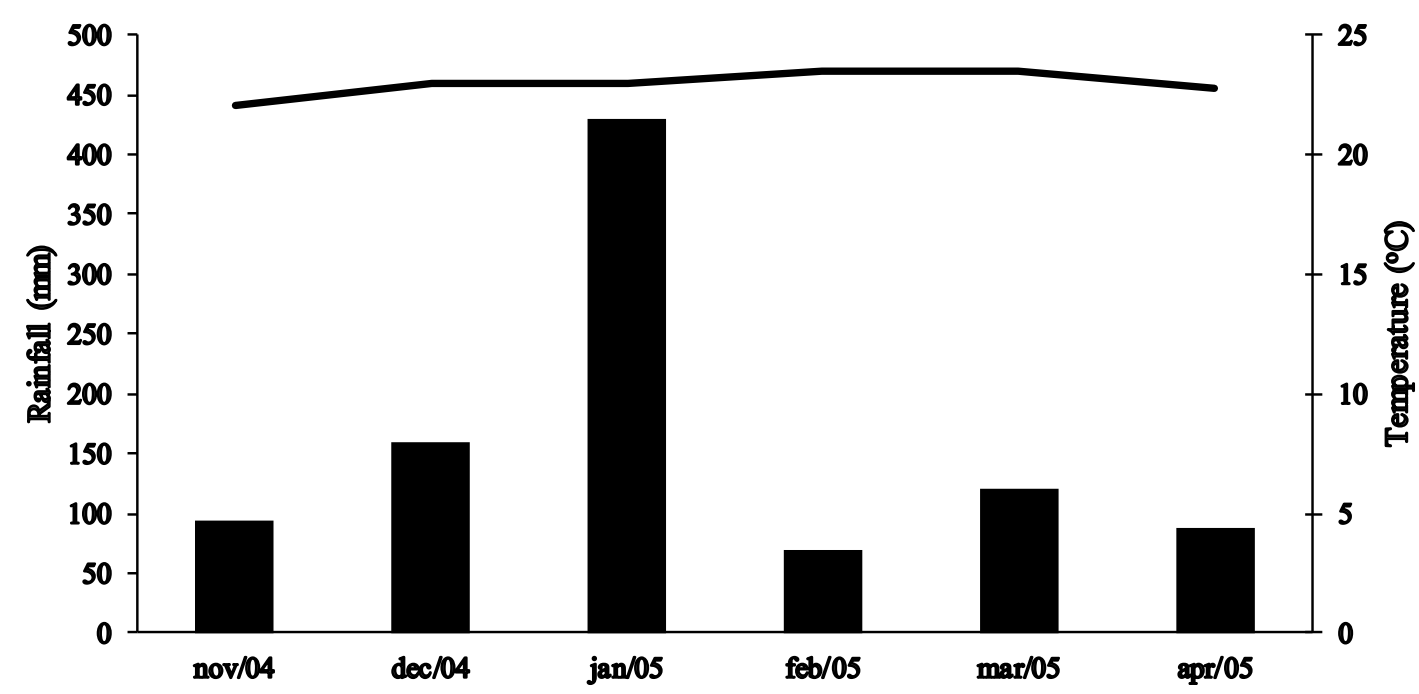

Figure 1. Total monthly rainfall ( ) and average monthly temperature (-) in the period of conducting the experiment.

The experiment was design in randomized blocks, with four replications, arranged as $2 \times 6$ factorial combination, two managements (with and without fragmentation) and six samplings of SDM $(0,18,32,46,74$ and 91 days after management (DAM)). The dimension of the plots was $5 \mathrm{~m}$ width and $15 \mathrm{~m}$ length, for a total of $75 \mathrm{~m}^{2}$.

Sowing of the pigeonpea was performed on $10 / 21 / 2004$, emergence of which occurred nine days afterward (10/30/2004). A quantity of $40 \mathrm{~kg} \mathrm{ha}^{-1}$ of seeds was used in a spacing of 0.17 $\mathrm{m}$ between rows and approximately $0.05 \mathrm{~m}$ depth. No fertilizer was applied, as well as cultural practices (pest and diseases control).

At 75 days after emergence (DAE), at time of flowering (01/14/2005), desiccation was carried out using glyphosate herbicide $(1.920 \mathrm{~g}$ a.i. ha $\left.^{-1}\right)$. After desiccation the mechanical management was performed by horizontal crusher straw (Triton) in predetermined plots.

Samplings of the SDM were made on the day of desiccation (0 DAM), on 02/01/2005 (18 DAM), on 02/15/2005 (32 DAM), on 03/01/2005 (46 DAM), on 03/29/2005 (74 DAM) and on 04/15/2005 (91 DAM). Three plots were sampled on each time period, with $0.25 \mathrm{~m}^{2}$ of internal area (simple samples), which constituted one compound sample per plot. The topographic profiling of the sample within the experimental units was performed in a crosswise direction, with random samplings points, excluding the 0.50 $\mathrm{m}$ at each end as a border.

The plant residues were subjected to a pre-cleaning for removal of larger soil particles. Then they were washed according to the methodology of Malavolta et al. (1997), although modified, i.e., without the use of detergent. Thus, the samples were shaken for a few seconds in deionized water in three successive portions, and then placed on paper toweling. It should be noted that not using detergent reduced exposure time to shaking in water and the number of successive portions, which reduced probable $\mathrm{K}$ losses from the SDM as much as possible (ROSOLEM et al., 2003). The samples were placed in paper bags and dried in a forced air circulation oven at $65^{\circ} \mathrm{C}$ until reaching constant weight, and then weighed for determination of SDM. The material was ground in a Wiley mill for determination of macronutrient (MALAVOLTA et al., 1997), carbon (TEDESCO, 1995) and silicon concentration (KORNDÖRFER et al., 2004).

The content of macronutrients, $\mathrm{C}$ and $\mathrm{Si}$ in the SDM were determined by the product of the amount of SDM and the concentration of the elements of the plant residue in each sampling. With these values, the degradation of SDM and the content of elements contained in it were calculated, and the data were expressed in $\mathrm{kg} \mathrm{ha}$ 1 . This result was also expressed in percentage (\%) through the calculation: content remaining of SDM or of each nutrient from the initial content in each time period, multiplied by 100 .

To describe SDM decomposition and the remaining content of the elements $(\mathrm{N}, \mathrm{P}, \mathrm{K}, \mathrm{Ca}$, $\mathrm{Mg}, \mathrm{S}, \mathrm{C}$ and $\mathrm{Si}$ ) in it, both in $\mathrm{kg} \mathrm{ha}^{-1}$ and in \%, the exponential mathematical model described by Thomas e Asakawa (1993) was used of the $X=$ $\mathrm{X}_{\mathrm{o}} \mathrm{e}^{-\mathrm{kt}}$ type, in which $\mathrm{X}$ is the content of SDM or of elements remaining after a period of time $t$, in days; Xo is the initial quantity of SDM or of 
elements; and $\mathrm{k}$ is the constant of residue decomposition or release of elements. With the $k$ value, the half-life time was calculated $(\mathrm{t} 1 / 2=$ 0.693/k) (PAUL; CLARK, 1989), which expresses the period of time necessary for half of the plant residue to decompose or for half of the elements contained in the SDM to be released. Applying the derivative first to the functions fitted to the data on SDM and content release of the elements, the daily rates of SDM decomposition and release of elements after management of the cover crops were calculated (ROSOLEM et al., 2003; KLIEMANN et al., 2006).
The data were initially tested in regard to the normality of distribution of the error (Lilliefors test / SAEG 5.0) and the homogeneity of their variances (Cochran and Bartlett tests / SAEG 5.0), thus verifying if they met the requirements for use of analysis of variance (Table 1). The mean values of the treatments of the type of plant cover factor were compared by the $t$ test (LSD) at $5 \%$ probability and the other data from the SDM collection period factor were fitted to mathematical functions at $5 \%$ probability.

Table 1. Analysis of variance for variables related to shoot dry matter (SDM), ratios between carbon, nutrients and Si concentration, content and percentage in the pigeonpea shoot dry matter (SDM) according to management (M) and days after management (DAM).

\begin{tabular}{|c|c|c|c|c|}
\hline \multirow{2}{*}{ Variable } & \multicolumn{3}{|c|}{ F Value } & \multirow{2}{*}{ CV $(\%$} \\
\hline & Management (M) & DAM (D) & $M \times D$ & \\
\hline SDM $\left(\mathrm{kg} \mathrm{ha}^{-1}\right)$ & $39,105^{* *}$ & $103,028 * *$ & $1,865 n s$ & 14,2 \\
\hline SDM (\%) & $50,906 * *$ & $137,146^{* *}$ & $2,508 \mathrm{~ns}$ & 12,1 \\
\hline C/N Ratio & $0,074 n s$ & $6,011 * *$ & $0,535 \mathrm{~ns}$ & 19,8 \\
\hline C/P Ratio & $0,849 \mathrm{~ns}$ & $4,188 * *$ & $0,360 \mathrm{~ns}$ & 17,9 \\
\hline C/S Ratio & $0,073 n s$ & $39,148 * *$ & $3,140 \mathrm{~ns}$ & 20,9 \\
\hline C/Si Ratio & $12,979 * *$ & $53,015 * *$ & $1,093 \mathrm{~ns}$ & 18,8 \\
\hline $\mathrm{N}\left(\mathrm{g} \mathrm{kg}^{-1}\right)$ & $2,906 \mathrm{~ns}$ & $26,880 * *$ & $0,390 \mathrm{~ns}$ & 16,8 \\
\hline$P\left(g_{k g}^{-1}\right)$ & $7,318^{*}$ & $10,845^{* *}$ & $0,499 n s$ & 16,7 \\
\hline $\mathrm{K}\left(\mathrm{g} \mathrm{kg}^{-1}\right)$ & $96,090 * *$ & $217,885^{* *}$ & $8,743^{* *}$ & 11,9 \\
\hline $\mathrm{Ca}\left(\mathrm{g} \mathrm{kg}^{-1}\right)$ & $1,719 \mathrm{~ns}$ & $13,554 \mathrm{~ns}$ & $1,030 \mathrm{~ns}$ & 13,3 \\
\hline $\operatorname{Mg}\left(\mathrm{g} \mathrm{kg}^{-1}\right)$ & $0,249 \mathrm{~ns}$ & $24,711^{* *}$ & $0,769 n s$ & 12,8 \\
\hline $\mathrm{S}\left(\mathrm{g} \mathrm{kg}^{-1}\right)$ & $5,501^{*}$ & $38,199 * *$ & $1,262 \mathrm{~ns}$ & 16,0 \\
\hline $\mathrm{C}\left(\mathrm{g} \mathrm{kg}^{-1}\right)$ & $48,524 * *$ & $8,403 * *$ & $1,089 \mathrm{~ns}$ & 8,0 \\
\hline Si $\left(\mathrm{g} \mathrm{kg}^{-1}\right)$ & $10,165^{* *}$ & $81,772^{* *}$ & $9,639 * *$ & 14,1 \\
\hline $\mathrm{N}\left(\mathrm{kg} \mathrm{ha}^{-1}\right)$ & $27,354^{* *}$ & $63,448 * *$ & $0,519 \mathrm{~ns}$ & 28,9 \\
\hline$P\left(\mathrm{~kg} \mathrm{ha}^{-1}\right)$ & $37,059 * *$ & $71,554^{* *}$ & $1,531 \mathrm{~ns}$ & 21,9 \\
\hline $\mathrm{K}\left(\mathrm{kg} \mathrm{ha}^{-1}\right)$ & $37,059 * *$ & $158,810 * *$ & $4,244^{* *}$ & 21,9 \\
\hline $\mathrm{Ca}\left(\mathrm{kg} \mathrm{ha}^{-1}\right)$ & $15,713^{* *}$ & $99,330 * *$ & $1,092 \mathrm{~ns}$ & 18,1 \\
\hline $\operatorname{Mg}\left(\mathrm{kg} \mathrm{ha}^{-1}\right)$ & $29,819 * *$ & $122,500 * *$ & $2,094 \mathrm{~ns}$ & 18,0 \\
\hline$S\left(\mathrm{~kg} \mathrm{ha}^{-1}\right)$ & $5,480^{*}$ & $61,610 * *$ & $0,254 \mathrm{~ns}$ & 27,0 \\
\hline$C\left(\mathrm{~kg} \mathrm{ha}^{-1}\right)$ & $26,726^{* *}$ & $80,550 * *$ & $1,684 \mathrm{~ns}$ & 18,4 \\
\hline $\mathrm{Si}\left(\mathrm{kg} \mathrm{ha}^{-1}\right)$ & $5,143^{*}$ & $2,558^{*}$ & $0,219 \mathrm{~ns}$ & 19,8 \\
\hline $\mathrm{N}(\%)$ & $33,806 * *$ & $200,626 * *$ & $1,932 \mathrm{~ns}$ & 15,7 \\
\hline $\mathrm{P}(\%)$ & $29,069 * *$ & $83,088 * *$ & $1,568 \mathrm{~ns}$ & 20,3 \\
\hline K (\%) & $144,859 * *$ & $601,121 * *$ & $16,918 * *$ & 11,3 \\
\hline $\mathrm{Ca}(\%)$ & $13,884^{* *}$ & $111,889 * *$ & $1,346 n s$ & 16,9 \\
\hline $\mathrm{Mg}(\%)$ & $36,861 * *$ & $161,872^{* *}$ & $2,723 n s$ & 15,6 \\
\hline S (\%) & $10,120 * *$ & $94,183 * *$ & $0,624 n s$ & 21,3 \\
\hline C (\%) & $45,081^{* *}$ & $141,980 * *$ & $2,594 \mathrm{~ns}$ & 13,5 \\
\hline Si (\%) & $4,025^{*}$ & $2,048^{*}$ & $0,189 n s$ & 20,5 \\
\hline
\end{tabular}

ns: not significant; ${ }^{*} p<0,05 ;{ }^{* *} p<0,01$. 


\section{RESULTS AND DISCUSSION}

The SDM of pigeonpea after 75 DAE was $4.720 \mathrm{~kg} \mathrm{ha}^{-1}$ (Figure 1A). SALMI et al. (2006) and CAVALCANTE et al. (2012), in Seropédica (RJ) with planting in October and Arapiraca (AL) in May, respectively, verified SDM during the flowering stage between 4.670-5.950 kg ha- in Seropédica and $4.000 \mathrm{~kg} \mathrm{ha}^{-1}$ in Arapiraca. Seropédica (RJ) has a tropical climate with rainy summer and dry winters and Arapiraca (AL) has dry summer with rains in the fall/winter period. Therefore, it is important to know the biomass production of plants used as cover crops in the different climatic conditions in agricultural regions, considering, among other factors, such as sowing time.

The SDM decomposition rates were similar between the managements adopted, with and without mechanical fragmentation, being the half-life after 46 DAM (Figure 2A). This half-life value indicates rapid mineralization (NASCENTE et al., 2014) and, in the last sampling (91 DAM), there were remained only $26 \%$ of the initial amount, evidencing the accelerated decomposition (Figure 2B). The decomposition was more intense in the period 0-18 DAM, with decomposition rate of $62 \mathrm{~kg} \mathrm{ha}^{-1} \mathrm{day}^{-1}$, reducing the intensity over time, thus in the period 75-91
DAM was $21 \mathrm{~kg} \mathrm{ha}^{-1} \mathrm{day}^{-1}$ (Table 2). In the literature, there are several reports about the higher decomposition rate at an early stage, with subsequent decrease (GIACOMINI et al., 2003; CRUSCIOL et al., 2005; SORATTO et al., 2012, DONEDA et al., 2012).

The $\mathrm{C} / \mathrm{N}, \mathrm{C} / \mathrm{P}, \mathrm{C} / \mathrm{S}$ and $\mathrm{C} / \mathrm{Si}$ ratios are indicative of the durability of the plant residue. At the desiccation moment the values were 18, 204, 350 and 45 , for $C / N, C / P, C / S$ and $C / S i$, respectively (Figures 2C, 2D, 2E and 2F). However, over time, due to the release of $\mathrm{N}, \mathrm{P}$ and $S$ from the SDM, the $C / N, C / P$ and $C / S$ increased, but the $\mathrm{C} / \mathrm{Si}$ decreased, reaching at the last sampling average values, respectively, 32, 284,927 and 13. Si is a component of compounds which are difficult to degrade because when absorbed by the plant is polymerized in the form of silica, strongly linked to cellulose and this can only be separated when mineralized (LEWIN; REIMANN, 1969). Thus, as the biomass degrades, the concentration of silicon increases in the plant residue, until this high concentration decreases the decomposition rate (Figure 2). It can be inferred that as the others ratios, the $\mathrm{C} / \mathrm{Si}$ is an important tool in the analysis of the degradation of biomass cover crops. 

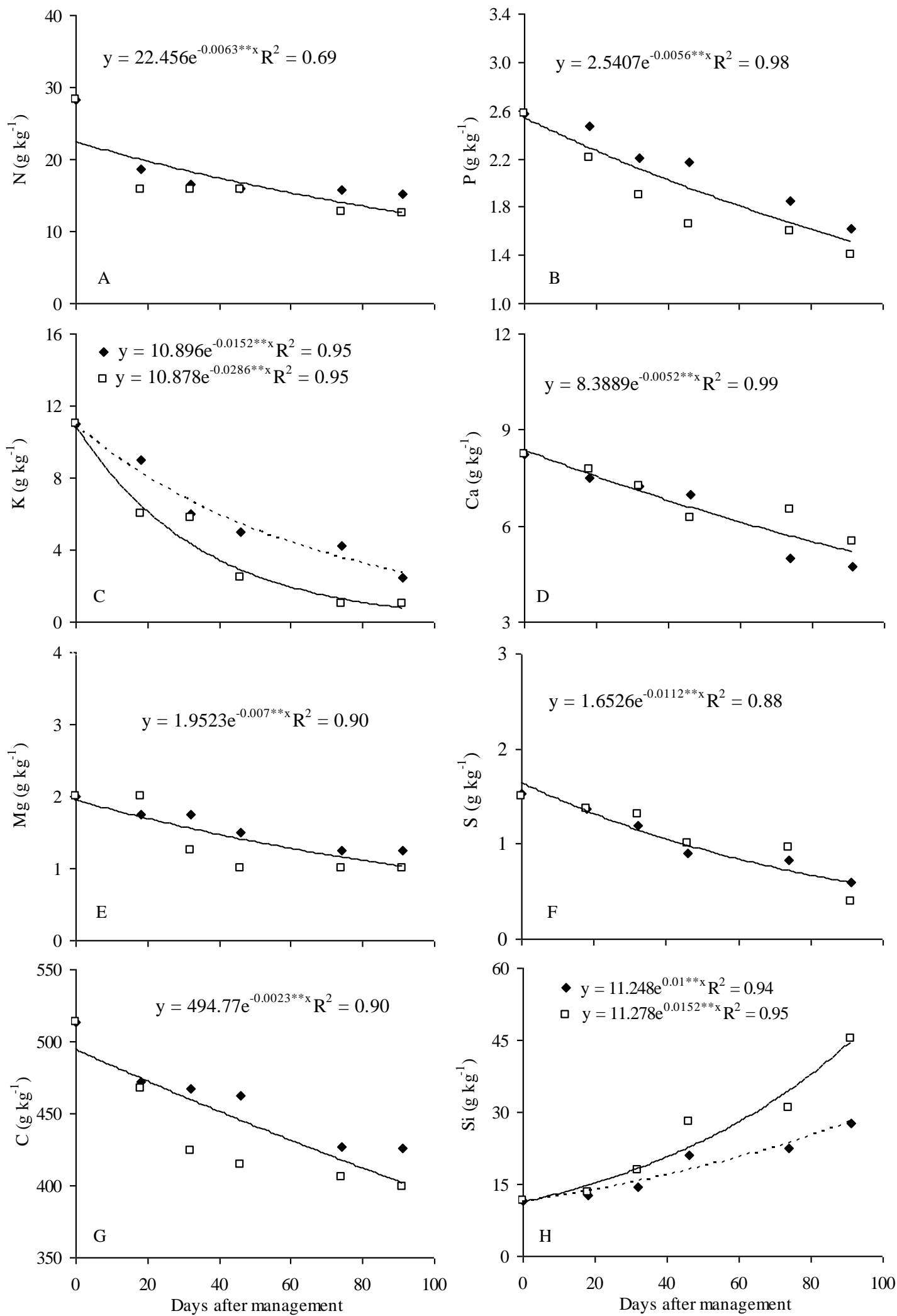

Figure 2. Shoot dry matter - SDM (A), percentage of plant shoot dry matter (B), $C / N(C), C / P(D), C / S(E)$ and $\mathrm{C} / \mathrm{Si}(\mathrm{F})$ ration of pigeonpea according to time after management, without $(\checkmark)$ e with $(\square)$ mechanical fragmentation. ${ }^{* *}$ Significant at $1 \%$ by test $\mathrm{F}$. The equations were adjusted based on the average management treatments. $T_{1 / 2}$ refers to the half-life time in DAM. 
Table 2. Rates of decomposition and daily releases of N, P, K, Ca, Mg, S, C e Si of pigeonpea shoot dry matter according to days after management (DAM), with or without mechanical fragmentation.

\begin{tabular}{|c|c|c|c|c|c|}
\hline \multirow{2}{*}{$\begin{array}{c}\text { Mechanical } \\
\text { fragmentation }\end{array}$} & \multicolumn{5}{|c|}{ Interval } \\
\hline & 0-18 DAM & 19-32 DAM & 33-46 DAM & 47-74 DAM & 75-91 DAM \\
\hline & \multicolumn{5}{|c|}{ SDM $\left(\mathrm{kg} \mathrm{ha}^{-1} \mathrm{day}^{-1}\right)$} \\
\hline Average & 62 & 49 & $\begin{array}{c}40 \\
\mathrm{~N}\left(\mathrm{~kg} \mathrm{ha}^{-1} \mathrm{day}^{-1}\right)\end{array}$ & 29 & 21 \\
\hline Average & \multicolumn{5}{|c|}{$\mathrm{P}\left(\mathrm{kg} \mathrm{ha}^{-1} \mathrm{day}^{-1}\right)$} \\
\hline Average & 0.2 & \multicolumn{3}{|c|}{$\mathrm{K}\left(\mathrm{kg} \mathrm{ha}^{-1} \mathrm{day}^{-1}\right)$} & 0.0 \\
\hline Without & 1.1 & 0.7 & 0.5 & 0.3 & 0.2 \\
\hline With & \multicolumn{5}{|c|}{$\mathrm{Ca}\left(\mathrm{kg} \mathrm{ha}^{-1} \mathrm{day}^{-1}\right)$} \\
\hline Average & \multicolumn{5}{|c|}{$\operatorname{Mg}\left(\mathrm{kg} \mathrm{ha}^{-1} \mathrm{day}^{-1}\right)$} \\
\hline Average & 0.2 & 0.1 & $\begin{array}{c}0.1 \\
\mathrm{~S}\left(\mathrm{~kg} \mathrm{ha}^{-1} \mathrm{day}^{-1}\right)\end{array}$ & 0.1 & 0.0 \\
\hline Average & 0.2 & 0.1 & $\begin{array}{c}0.1 \\
\mathrm{C}\left(\mathrm{kg} \mathrm{ha}^{-1} \mathrm{day}^{-1}\right)\end{array}$ & 0.0 & 0.0 \\
\hline Average & 35 & 26 & 21 & 15 & 10 \\
\hline & \multicolumn{5}{|c|}{ Si $\left(\mathrm{kg} \mathrm{ha}^{-1} \mathrm{day}^{-1}\right)$} \\
\hline Average & 0.2 & 0.2 & 0.1 & 0.1 & 0.1 \\
\hline
\end{tabular}

At the moment of management, the concentrations of $\mathrm{N}, \mathrm{P}, \mathrm{K}, \mathrm{Ca}, \mathrm{Mg}, \mathrm{S}, \mathrm{C}$ and $\mathrm{Si}$ were, respectively, 28, 2.6, 11, 8.3, 2.0, 1.5, 514 and $11.5 \mathrm{~g} \mathrm{~kg}^{-1}$ (Figure 3). Teixeira et al. (2005), in comparison with this study, observed lower concentrations of $\mathrm{N}, \mathrm{P}, \mathrm{K}, \mathrm{Ca}, \mathrm{Mg}$ and $\mathrm{S}$ in the shoot dry matter of pigeonpea at the beginning of flowering.

The macronutrients concentration was reduced over time, following the SDM decomposition (Figure 2). However, the management $x$ time interaction was observed only for the K (Table 1). The fragmentation of the biomass have increased the $\mathrm{K}$ release to the soil because the $\mathrm{K}$ concentration in the SDM without fragmentation were 11.0, 9.0, 6.0, 5.0, 4.3 and $2.5 \mathrm{~g} \mathrm{~kg}^{-1}$, and with fragmentation were 11.0, 60 ,
5.8, 2.5, 1.0 and $1.0 \mathrm{~g} \mathrm{~kg}^{-1}$, respectively, $0,18,32$, 46, 74 and DAM 91 (Figure 3).

The accelerated release of $\mathrm{K}$ from biomass was also observed by Crusciol et al. $(2005,2008)$, in oilseed radish and oats. This occurs because $\mathrm{K}$ is not associated with any structural component of plant tissue and is not metabolized in the plant and forms bonds with easily reversible organic complexes (MARSCHNER, 2012). Thus, as the shoot of the plants begins the drying process and degrades, the concentration of this nutrient in the tissue decreases drastically because it is easily carried away by rainwater (KHATOUNIAN, 1999) after rupture of the plasmatic membrane (MALAVOLTA et al., 1997). 

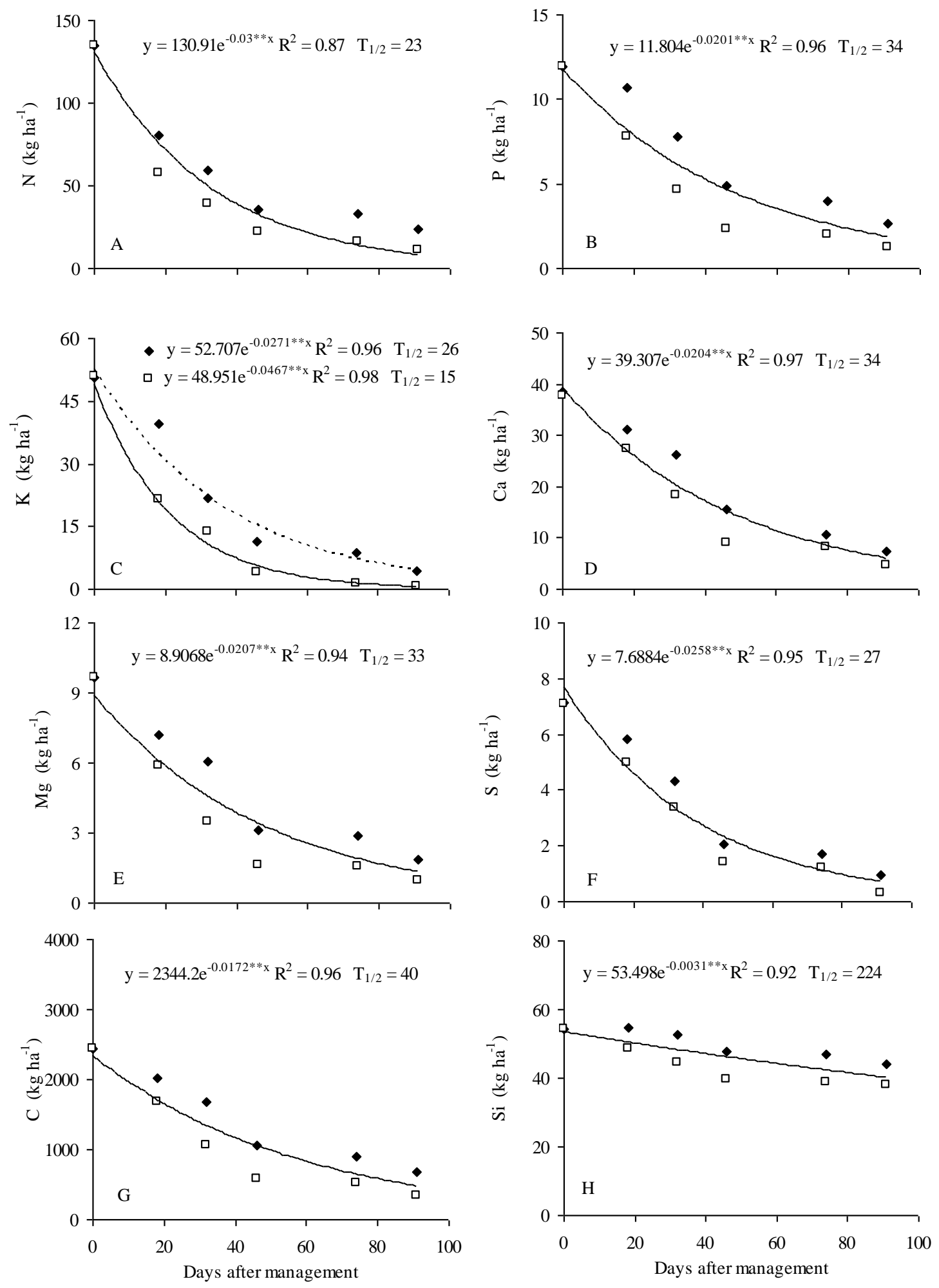

Figure 3. $N(A), P(B), K(C), C a(D), M g(E), S(F), C(G)$ e $S i(H)$ concentration of pigeonpea shoot dry matter according to time after management, without $(\checkmark)$ e with $(\square)$ mechanical fragmentation. ${ }^{* *}$ Significant at $1 \%$ by test $\mathrm{F}$. The equations relating the concentrations of $\mathrm{N}, \mathrm{P}, \mathrm{Ca}, \mathrm{Mg}, \mathrm{S}, \mathrm{Si}$ and $\mathrm{C}$ were adjusted based on the average management treatments.

In contrast to other nutrients the $\mathrm{Si}$ concentration increased over sampling, and after 91 DAM, $140 \%$ and $293 \%$ higher than the initial values, respectively, with and without fragmentation (Figure $3 \mathrm{H}$ ).

At the time of desiccation, the contents of $\mathrm{N}, \mathrm{P}, \mathrm{K}, \mathrm{Ca}, \mathrm{Mg}, \mathrm{S}, \mathrm{C}$ and $\mathrm{Si}$ in the SDM of 
pigeonpea were approximately $135,12,51,38$, $10,7,2,434$ and $54 \mathrm{~kg} \mathrm{ha}^{-1}$ (Figure 4). These values correspond to the quantities that can be recycled by pigeonpea.

Calvo et al. (2010) observed lower $\mathrm{N}$ contents than this study. They sowed the pigeonpea on March on an Ultisol, in Presidente Prudente-SP, the region has hot summer and dry winter, and 90 days after sowing it was observed a content of $64 \mathrm{~kg} \mathrm{ha}^{-1} \mathrm{~N}$. The climatic conditions of each study for growing pigeonpea have directly influenced the contents of $\mathrm{N}$.

Compared with other species such as oilseed radish and black oat, the pigeonpea accumulated higher amounts of $\mathrm{N}$ and $\mathrm{Ca}$ (CRUSCIOL et al., 2005; 2008). However, the difference was significant only for $\mathrm{N}$, higher in 78 and $65 \mathrm{~kg} \mathrm{ha}^{-1}$ compared to values observed in SDM oilseed radish and oats, respectively.

The nutrients release from SDM over time was significant, regardless of the adopted management (Figure 4). Thus, at 91 DAM remained 9, 2, 3, 6, 1, 1 and $490 \mathrm{~kg} \mathrm{ha}^{-1}$, respectively, $\mathrm{N}, \mathrm{P}, \mathrm{K}, \mathrm{Ca}, \mathrm{Mg}, \mathrm{S}$ and $\mathrm{C}$, and providing about 122, 10, 49, 33, 8, 7 and $1854 \mathrm{~kg}$ $\mathrm{ha}^{-1}$, respectively. In terms of NPK were released to the soil the equivalent to $125,23,5$ and $61 \mathrm{~kg}$ ha ${ }^{-1}$ of $\mathrm{N}_{1} \mathrm{P}_{2} \mathrm{O}_{5}$ and $\mathrm{K}_{2} \mathrm{O}$, respectively.

Regarding the $\mathrm{K}$, the initial release was more pronounced with the fragmentation of SDM. The fragmentation increases the contact surface with the soil, facilitating its release, so the time to released $50 \%$ into the soil was 15 days, whereas without fragmentation occurred at 26 days (Figure 4C). It is noteworthy that, at 91 $\mathrm{DAM}$, the amount of $\mathrm{K}$ released to the soil were similar. Similar results have been observed by several authors for this nutrient in differents cover crops species (CRUSCIOL et al., 2008; PACHECO et al., 2011).

However, considering the $\mathrm{Si}$ average values after 91 DAM only $13 \mathrm{~kg} \mathrm{ha}^{-1}$ were released, and the estimated time to release $50 \%$ was 224 days. Within this context, the last evaluation still remained in the SDM $75 \%$ of the accumulated $\mathrm{Si}$ (Figure $4 \mathrm{H}$ ). So there was a great accumulation of $\mathrm{Si}$ in pigeonpea SDM, with subsequent slow release of this element in the soil. 

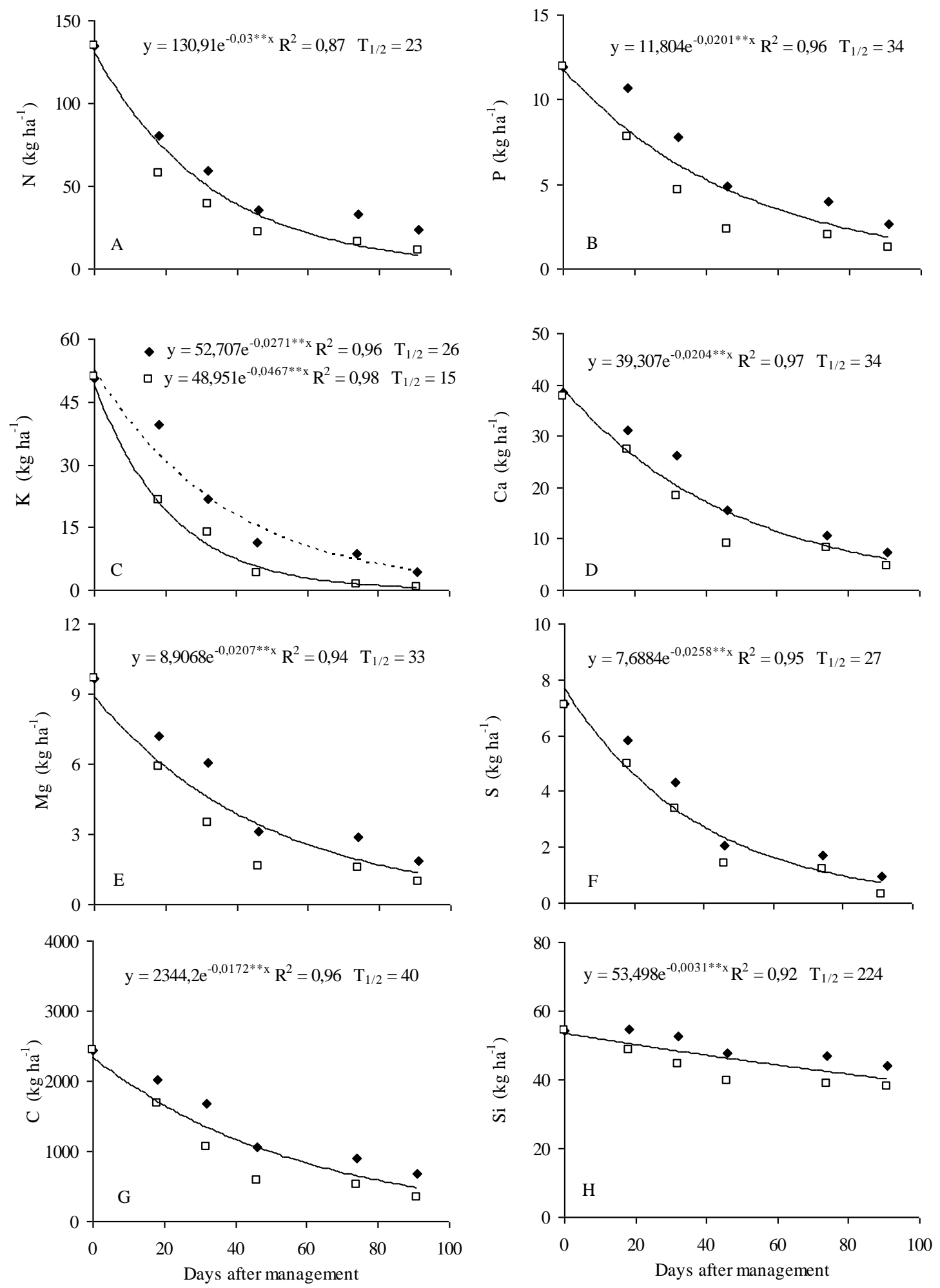

Figure 4. Content remaining of $N(A), P(B), K(C), C a(D), M g(E), S(F), C(G)$ e Si (H) in pigeonpea shoot dry matter according to time after management, without $(\checkmark)$ e with $(\square)$ mechanical fragmentation.

**Significant at $1 \%$ by test $\mathrm{F}$. The equations relating the contents of $\mathrm{N}, \mathrm{P}, \mathrm{Ca}, \mathrm{Mg}, \mathrm{S}, \mathrm{Si}$ and $\mathrm{C}$ were adjusted based on the average management treatments.

At 91 DAM It had already been released $90,84,96,87,88,94,76$ and $25 \%$ of $\mathrm{N}, \mathrm{P}, \mathrm{K}, \mathrm{Ca}$, $\mathrm{Mg}, \mathrm{S}, \mathrm{C}$ and $\mathrm{Si}$, respectively (Figure 5 ). In addition, substantial portions of nutrients were released, which could supply the needs of the next crop. Because $50 \%$ of the total quantity of $\mathrm{N}$, $\mathrm{P}, \mathrm{K}, \mathrm{Ca}, \mathrm{Mg}, \mathrm{S}$ and $\mathrm{C}$ in the SDM had been released, respectively, 23, 34, 21, 34, 33, 27 and 40 DAM (Figure 4). It is evident that recycling and nutrient retention by cover crops always 
minimize the risk of leaching losses (AITA et al.,

1994).
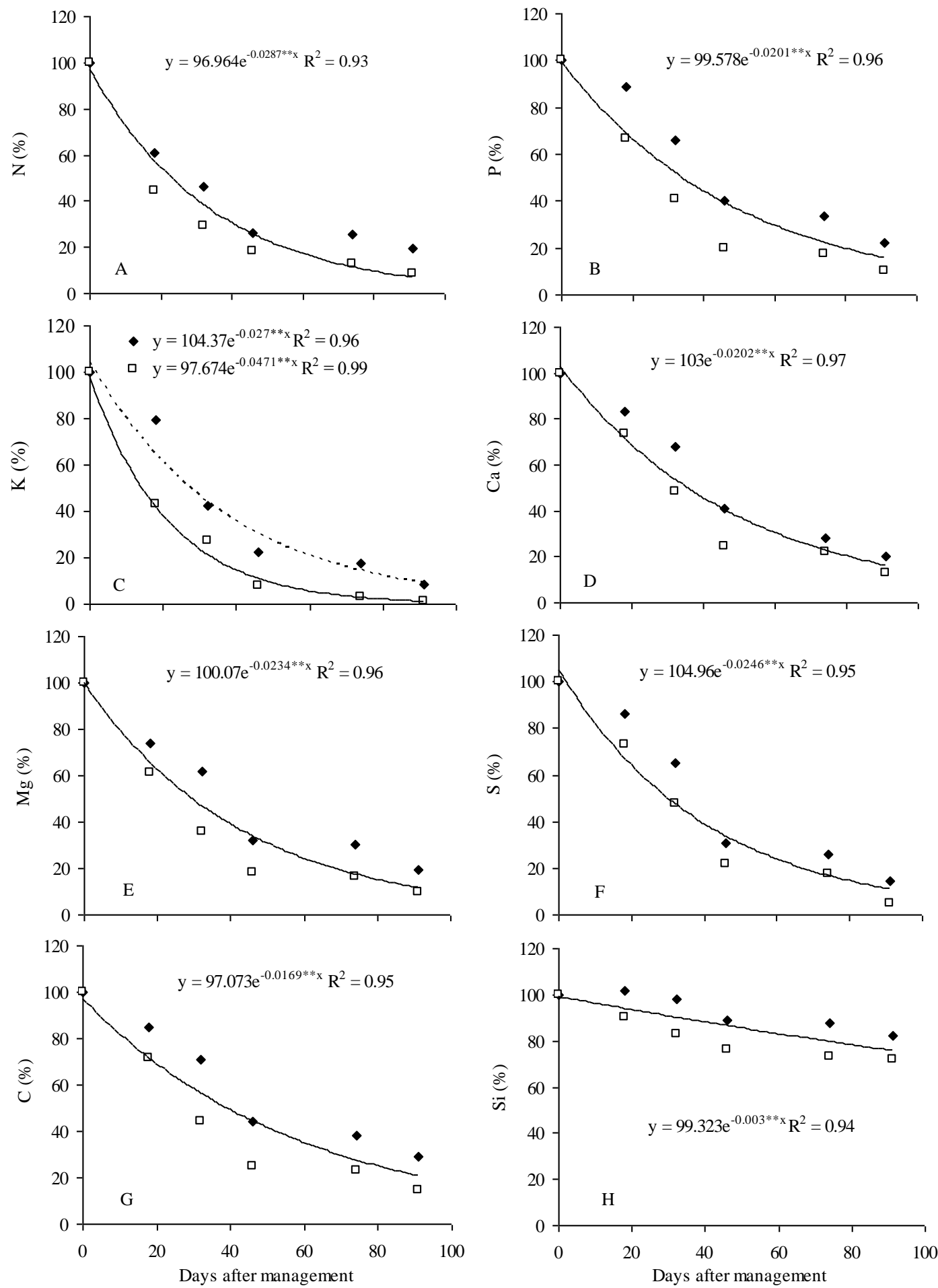

Figure 5. Percentages of $N(A), P(B), K(C), C a(D), M g(E), S(F), C(G)$ e Si $(H)$ in pigeonpea shoot dry matter according to time after management, without $(*)$ and with $(\square)$ mechanical fragmentation. ${ }^{* *}$ Significant at $1 \%$ by test $\mathrm{F}$. The equations relating the percentage of $\mathrm{N}, \mathrm{P}, \mathrm{Ca}, \mathrm{Mg}, \mathrm{S}, \mathrm{Si}$ and $\mathrm{C}$ were adjusted based on the average management treatments.

\section{CONCLUSIONS}

The mechanical fragmentation of pigeonpea shoot dry matter did not alter the decomposition and the release of $\mathrm{N}, \mathrm{P}, \mathrm{Ca}, \mathrm{Mg}$ and $S$, and the maximum daily release rates occurred between 0-18 DAM. The $\mathrm{K}$ was the most quickly released nutrient, especially with the fragmentation of shoot dry matter. After 91 DAM at least $85 \%$ of all macronutrients were released to the soil. The release of Si was low being 
proportionally less than the degradation rate, which resulted in, increased the concentration over time, especially with mechanical fragmentation.

\section{ACKNOWLEDGEMENTS}

The authors would like to thank the São Paulo Research Foundation (FAPESP) for financial support (Registry numbers: 2004/10361-1) and the National Council for Scientific and Technological Development (CNPq) for an award for excellence in research to the second and third author.

$\&$ pid $=$ S0006-

$87052008000200024 \&$ Ing=pt\&t|ng=pt $>$

DENARDIN, J.E.; KOCHHAN, R.A. Requisitos para implantação e a manutenção do sistema plantio direto. In: Plantio Direto no Brasil. EMBRAPACNPT;FECOTRIGO-FUNDACEP;FUNDAÇÃO ABC, Passo Fundo, p.19-27, 1993.

DONEDA, A.; AITA, C.; GIACOMINI, S.J.; MIOLA, E.C.C.; GIACOMINI, D.A.; SCHIRMANN, J.; GONZATTO, R. Fitomassa e decomposição de resíduos de plantas de cobertura puras e consorciadas. Revista Brasileira de Ciência do Solo, Viçosa, v.36, p.1714-1723, 2012. https://doi.org/10.1590/\$0100-

$\underline{06832012000600005}$

EMBRAPA. Sistema brasileiro de classificação de solos. 3.ed. Rio de Janeiro: Embrapa Solos, 2013. 353p.

GIACOMINI, S.J.; AITA, C.; VENDRUSCOLO, E.R.O.; CUBILLA, M.; NICOLOSO, R.S.; FRIES, M.R. Matéria seca, relação $\mathrm{C} / \mathrm{N}$ e acúmulo de nitrogênio, fósforo e potássio em misturas de plantas de cobertura de solo. Revista Brasileira de Ciência do Solo, Viçosa, v.27, p. 325-334, 2003. https://doi.org/10.1590/S0100$\underline{06832003000200012}$

KHATOUNIAN, C.A. O manejo da fertilidade em sistemas de produção. In: CASTRO FILHO, C.; MUZILLI, O. (Coord.). Uso e manejo dos solos de baixa aptidão agrícola. Londrina, IAPAR, 1999. p.179-221. (Circular, 108).

KLIEMANN, H.J.; BRAZ, A.J.P.B.; SILVEIRA, P.M. Taxas de decomposição de resíduos de espécies de cobertura em latossolo vermelho distroférrico. Pesquisa Agropecuária Tropical, Goiânia, v.36, p.21-28, 2006. Disponível em: $<w w w$. revistas.ufg.br/index.php/pat/article/dow nload/2165/2116> 
KORNDÖRFER, G. H.; PEREIRA, H. S.; NOLA, A. Análise de silício: solo, planta e fertilizante. Uberlândia: GPSi-ICIAG-UFU, 2004. 34 p. (Boletim técnico, 2).

LEWIN, J.; REIMANN, B.E.F. Silicon and plant growth. Plant Physiology, v.20, p.289-304, 1969. https://doi.org/10.1146/annurev.pp.20.060169.0 01445

MALAVOLTA, E. et al. Avaliação do estado nutricional de plantas: princípios e aplicações. Piracicaba: Potafos, 1997. 308p.

MARSCHNER, $H$. Mineral nutrition of higher plants. Amsterdam: Elsevier/Academic Press, 2012. 684p.

NASCENTE, A. S.; CRUSCIOL, C. A. C.; STONE, L. F. Straw degradation and nitrogen release from cover crops. Revista Caatinga, Mossoró, v.27, n.2, p.166-175, 2014. Disponível em: <http://periodicos.ufersa.edu.br/revistas/index.p hp/sistema/article/view/3278>

PACHECO, L.P.; LEANDRO, W.M.; MACHADO, RENATO LARA DE ASSIS, P.L.O.A.; COBUCCI, T.; MADARI, B.E.; PETTER, F.A. Produção de fitomassa e acúmulo e liberação de nutrientes por plantas de cobertura na safrinha. Pesquisa Agropecuária Brasileira, Brasília, v.46, p.17- 25, 2011. Disponível em:

<http://seer.sct.embrapa.br/index.php/pab/articl e/view/9443/0>

PARIZ, C.M.; ANDREOTTI, M.; BUZETTI, S.; BERGAMASCHINE, A.F.; ULIAN, N.A.; FURLAN, L.C.; MEIRELLES, P.R.L.; CAVASANO, F.A. Straw decomposition of nitrogen-fertilized grasses intercropped with irrigated maize in an integrated crop-livestock system. Revista Brasileira de Ciência do Solo, Viçosa, v.35, p.2029-2037, 2011.

https://doi.org/10.1590/S0100-

$\underline{06832011000600019}$

PAUL, E.A.; CLARK, F.E. Soil microbiology and biochemistry. San Diego: Academic Press, 1989. $275 p$.

PEGADO, C.M.A.; BARBOSA, L.J.N.; MENDES, J.E.M.F.; SOUTO, P.C.; SOUTO, J.S. Decomposição superficial e subsuperficial de folhas de fava
(Phaseolus lunatus L.) na região do brejo da Paraíba. Revista Caatinga, Mossoró, v. 21, n. 1, p. 218-223, 2008. Disponível em: $<$ http://periodicos.ufersa.edu.br/revistas/index.p hp/sistema/article/view/631>

ROSOLEM, C.A.; CALONEGO, J.C.; FOLONI, J.S.S. Lixiviação de potássio da palhada de espécies de cobertura de solo de acordo com a quantidade de chuva aplicada. Revista Brasileira de Ciência do Solo, Viçosa, v.27, p.355-362, 2003. https://doi.org/10.1590/s0100$\underline{06832003000200015}$

SALMI, G.P.; SALMI, A.P.; ABBOUD, A.C.S. Dinâmica de decomposição e liberação de nutrientes de genótipos de guandu sob cultivo em aléias. Pesquisa Agropecuária Brasileira, Brasília, v.41, p.673-678, 2006. https://doi.org/10.1590/S0100$\underline{204 \times 2006000400019}$

SILVA, L.S.; BOHNEN, H. Rendimento e acúmulo de nutrientes pelo arroz em solução nutritiva com e sem a adição de silício. Revista Brasileira de Ciência do Solo, Viçosa, v.25, p.771-777, 2001. https://doi.org/10.1590/S0100$\underline{06832001000300027}$

SORATTO, R.P.; CRUSCIOL, C.A.C.; COSTA, C.H.M., FERRARI NETO, J.; CASTRO, G.S.A. Produção, decomposição e ciclagem de nutrientes em resíduos de crotalária e milheto, cultivados solteiros e consorciados. Pesquisa Agropecuária Brasileira, Brasília, v.47, p.1462-1470, 2012. https://doi.org/10.1590/S0100$\underline{204 \times 2012001000008}$

TEDESCO, M.J. Análises de solo, plantas e outros materiais. Porto Alegre: Universidade Federal do Rio Grande do Sul, 1985. 188p. (Boletim técnico, 5).

TEIXEIRA, C.M.; CARVALHO, G.J.; FURTINI NETO, A.E.; ANDRADE, M.J.B.; MARQUES, E.L.S. Produção de biomassa e teor de macronutrientes do milheto, feijão-de-porco e guandu-anão em cultivo solteiro e consorciado. Ciência \& Agrotecnologia, Lavras, v.29, p.93-99, 2005. https://doi.org/10.1590/S1413$\underline{70542005000100011}$

TEIXEIRA, C.M.; CARVALHO, G.J.; ANDRADE, M.J.B.; SILVA, C.A.; PEREIRA, J.M. Decomposição 
e liberação de nutrientes das palhadas de milheto e milheto + crotalária no plantio direto do feijoeiro. Acta Scientiarum. Agronomy, Maringá, v.31, p.647-653, 2009. https://doi.org/10.4025/actasciagron.v31i4.1356

THOMAS, R.J.; ASAKAWA, N.M. Decomposition of leaf litter from tropical forage grasses and legumes. Soil Biology \& Biochemistry, n.25, p.1351-1361, 1993. https://doi.org/10.1016/0038-0717(93)90050-L

TORRES, J.L.R.; PEREIRA, M.G.; FABIAN, A.J. Produção de fitomassa por plantas de cobertura e mineralização de seus resíduos em plantio direto. Pesquisa Agropecuária Brasileira, Brasília, v.43, p.421-428, 2008. Disponível em: http://seer.sct.embrapa.br/index.php/pab/article $\Delta$ view/70

Recebido para publicação em 16/12/2016

Revisado em 16/02/2017

Aceito em 27/03/2017 